\title{
Yellow fever in two unvaccinated French tourists to Brazil, January and March, 2018
}

Emma Oliosi ${ }^{1}$, Chantal Serero Corcos², Paulo Feijo Barroso ${ }^{3}$, Alexandre Bleibtreu ${ }^{1}$, Gilda Grard4, Bispo Ana Maria De Filippis5, Eric Caumes ${ }^{1}$

1. Département des Maladies Infectieuses et Tropicales, Hôpital Pitié-Salpêtrière, Sorbonne Université, Paris, France

2. Consulat général de France à Rio de Janeiro, Brazil

3. Hospital Universitario Clementino Fraga Filho, Rio de Janeiro, Brazil

4. Centre national de référence des arbovirus, HIA Laveran, Marseille, France

5. Fundaçao Oswaldo Cruz, Rio de Janeiro, Brazil

Correspondence: Emma Oliosi (emma.oliosi@gmail.com)

We report two yellow fever cases in unvaccinated French travellers in Brazil in January and March 2018, respectively; one exposed during an excursion in Minas Gerais and the other in Ilha Grande. Both presented with fever, hepatitis, thrombocytopenia and leucopenia. Yellow fever diagnosis was based on RT-PCR and serological tests. Both patients recovered within a few days. The increasing occurrence of cases in unvaccinated travellers highlights the need to reinforce vaccination recommendation for travellers at-risk.

Since late 2016, a growing number of confirmed yellow fever (YF) cases have been reported in Brazil $[1,2]$. In the monitoring period, between 1 July 2017 and 27 March 2018, there were 1,131 confirmed human cases of YF, including 338 deaths, and a major increase was observed during the first weeks of 2018 compared with the preceding season [3].

Among international travellers in South America, five cases, including two deaths, were reported between July 2016 and March 2017 [4-6]. In January and February 2018, 11 cases have been declared according to the latest updates, including one of the cases presented in this article $[1,2]$. Here we report details of two cases of $\mathrm{YF}$ in unvaccinated French travellers in Brazil in January and March 2018, respectively.

\section{Case report 1}

On 14 January 2018, a French woman in her early 40ies was referred to a medical clinic in Rio de Janeiro because of high fever, vomiting and myalgia. Symptoms had started on 10 January; she had no known comorbidities and was not vaccinated against YF.

She had arrived in Brazil on 28 December 2017 and stayed in Rio de Janeiro until 7 January 2018. Hereafter, she stayed for 2 days in the city of Simao Pereira, Mina
Gerais region, moving to the city of Brumadinho on 10 January where she visited the Inhotim botanical garden. She returned to Rio de Janeiro on 11 January.

Upon admission, clinical examination showed no clinical signs and symptoms apart from fever, vomiting and myalgia. Blood tests revealed severe leucopenia (white blood cell (WBC) count at $830 / \mathrm{mm}^{3}$; norm: $\left.4,000-10,000 / \mathrm{mm}^{3}\right)$ with neutropenia $\left(457 / \mathrm{mm}^{3}\right.$; norm: $\left.1,600-7,000 / \mathrm{mm}^{3}\right)$, lymphopenia $\left(274 / \mathrm{mm}^{3}\right.$; norm: $\left.1,500-4,000 / \mathrm{mm}^{3}\right)$, as well as thrombocytopenia (91,000/mm3 ; norm: $\left.150,000-500,000 / \mathrm{mm}^{3}\right)$ whereas haemoglobin was normal $(14.9 \mathrm{mg} / \mathrm{L}$; norm: $12-16 \mathrm{~g} /$ $\mathrm{dL}$ ). Liver blood tests showed a severe liver injury with increased levels of serum glutamic oxaloacetic transaminase (SGOT) (2,276 U/L norm: 6-25 U/L) and serum glutamic pyruvic transaminase (SGPT) $(2,700$ $\mathrm{U} / \mathrm{L}$ norm: 6-25 U/L) without cholestasis. Activated partial thromboplastin time (PTT) was 1.73 ( $\mathrm{n}<1.2 \mathrm{sec}$ ), but despite being elevated, there was no haemorrhage. Moreover, there was no renal impairment.

On 17 January a blood Real Time-PCR detected YF virus RNA and YF virus IgM antibodies were found to be positive. Dengue IgM antibodies were also found to be positive on blood samples on the same date. Serological findings for other viruses (hepatitis A virus, hepatitis $B$ virus, chikungunya virus, Zika virus) did not show anything relevant. The patient was not vaccinated against tick-borne encephalitis.

With supportive care, the patient got better within a few days. Consecutive blood tests on 17 January showed a worsening thrombocytopenia with platelets dropping to $49,000 / \mathrm{mm}^{3}$, without any haemorrhagic complications. Thereafter, the haematological and liver abnormalities improved quickly. 
Reported cases of yellow fever in international travellers returning from Brazil between January and March 2018 ( $\mathrm{n}=12$ )

\begin{tabular}{|l|c|c|c|c|c|c|}
\hline Case & Sex & Age group & Country of origin & Place of exposure & Outcome & $\begin{array}{c}\text { Information obtained from } \\
\text { reference }\end{array}$ \\
\hline 1 & M & $40-19$ & The Netherlands & Mairipora & Alive & {$[1,2]$} \\
\hline 2 & F & $40-49$ & France & Minas Gerais & Alive & {$[1,2]$ and this article } \\
\hline 3 & M & $30-39$ & Romania & Ilha Grande & Alive & {$[1,2]$} \\
\hline 4 & M & $40-49$ & Switzerland & Ilha Grande & Dead & {$[1,2]$} \\
\hline 5 & M & $30-39$ & UK & Ilha Grande & Dead & {$[1,2]$} \\
\hline 6 & F & $40-49$ & Argentina & Ilha Grande & Alive & {$[1,2]$} \\
\hline 7 & M & $20-29$ & Argentina & Ilha Grande & Alive & {$[1,2]$} \\
\hline 8 & F & $20-29$ & Argentina & Salvador & Alive & {$[2]$} \\
\hline 9 & M & $30-39$ & Chile & Ilha Grande & Dead & {$[1,2]$} \\
\hline 10 & M & $20-29$ & Chile & Ilha Grande & Dead & {$[1,2]$} \\
\hline 11 & Not available & Not available & Chile & Ilha Grande & Alive & {$[1,2]$} \\
\hline 12 & F & $30-40$ & France & Ilha Grande & Alive & This article \\
\hline
\end{tabular}

The patient was discharged on 19 January and returned to France on 9 days later. On 14 February, she was assessed at our Infectious disease department in Paris and appeared to have clinically fully recovered. Blood tests were within normal range for white blood cell counts, and platelets, whereas liver enzymes remained elevated (SGPT $171 \mathrm{U} / \mathrm{L}$, SGOT $87 \mathrm{U} / \mathrm{L}$ ).

\section{Case report 2}

On 3 March 2018, a French woman in her early zoies was admitted to hospital in Rio de Janeiro because of fever, nausea and headache. She had no known comorbidities and was not vaccinated against YF.

She had arrived in Brazil on 20 February 2017 and stayed in Rio de Janeiro for 2 days before heading to Ilha Grande for a further 2 days, before returning to Rio de Janeiro on the 25 February. Initial symptoms (fever, headache) started on 26 February.

Blood tests revealed leucopenia (WBC count at 2,070/ $\mathrm{mm}^{3}$ ) with neutropenia $\left(704 / \mathrm{mm}^{3}\right)$, as well as thrombocytopenia $\left(87,000 / \mathrm{mm}^{3}\right)$ whereas haemoglobin was found to be within normal range $(14.2 \mathrm{mg} / \mathrm{L})$. Liver blood tests showed a moderate liver injury with increased levels of SGOT (202 U/L) and SGPT (254 U/L) without cholestasis. The diagnosis of YF was suspected when IgM and IgG antibodies were found to be positive on the blood samples taken on her admittance to the hospital. With symptomatic treatment, she got better within a few days and was discharged on 11 March.

She came back to France on 14 March and presented in our department for follow-up 2 days later. Using ELISA test, we found a positive result for YF virus IgM and IgG antibodies, as well as dengue and West Nile virus antibodies. On 21 April, following subsequent testing, YF virus IgM and IgG antibodies were still positive whereas dengue and West Nile virus antibodies were found to be negative. This most likely indicates that there was a cross-reaction between flaviviruses for the first serologic testing. She showed a normal range of white blood cells and platelets, while liver tests were still slightly above the norm (SGPT $33 \mathrm{U} / \mathrm{L}$ and SGOT 75 $\mathrm{U} / \mathrm{L}$ ). There was no renal impairment.

\section{Discussion}

These two cases of YF in travellers returning from Brazil confirm that travellers are epidemiological sentinels and that imported cases parallel ongoing outbreaks when they take place in locations with a high level of tourism.

In Brazil, during the monitoring period 2016/17, there were a total of 660 YF cases including 210 deaths [7]. During the $2017 / 18$ monitoring period, 475 cases of YF, including 147 deaths, were reported in the state of Minas Gerais where our first case was possibly exposed [3]. Considering the incubation period of YF, the most likely place of exposure is the city of Simao Pereira, rather than the Inhotim botanical garden, but both are considered as high-risk areas. In the state of Rio de Janeiro, which includes Ilha Grande where our second case had been exposed, 176 cases including 63 deaths were reported in 2018 [3]. For our second case, Rio de Janeiro cannot be ruled out as a place of infection, but the number of cases reported in Ilha Grande and the lack of cases in Rio de Janeiro city argue for initial exposure in Itha Grande.

From 1970 through 2015, 10 cases of YF were reported in unvaccinated international travellers, from Europe and the United States. Five patients had travelled to West Africa, and five to South America. Eight of these 10 travellers died. Only one case of YF in a vaccinated traveller was ever reported in a traveller from Spain 
who visited a few West African countries in 1988 [8]. In 2016, three cases of YF in international travellers returning from South America were reported. One was a fatal case in an unvaccinated American traveller to Peru [5]. The two remaining cases, including one fatal, occurred in unvaccinated French travellers to Peru [4]. Also in 2016, 11 cases were reported in Chinese travellers and workers who had visited Angola during an outbreak of YF [9]. In 2017, one case occurred in an unvaccinated Dutch traveller who had visited Suriname [6] and the second occurred in an unvaccinated Danish citizen travelling to Bolivia [8]. There were no reported cases in travellers from central Africa in 2017.

Between January and March 2018, 11 unvaccinated cases have been reported in travellers returning from Brazil, excluding case 2 but including case 1 presented here [1]. The cases were from France, the Netherlands, Switzerland, Romania, the United Kingdom, Argentina and Chile [1,2] and are described in more detail in Table. Eight of the 11 cases had travelled to Ilha Grande and four died [2]. Since 2016, YF cases have increased in international travellers compared with the past 50 years.

YF vaccine is recommended for people who are travelling to high-risk areas in South America. A single dose is usually recommended, but the $C D C$, as well as the French authorities, recommend a booster dose for some travellers $[10,11]$. Our first case had not been vaccinated before her travel because she had initially planned to stay in Rio de Janeiro City during the whole trip, where according to the website she consulted (not specified) the vaccination was not mandatory. She therefore likely acquired YF during an unplanned excursion to the State of Minas Gerais illustrating that deviations from the travel itinerary and type of accommodation can be a major issue in pre-travel consultations. According to a study, including 89 travellers, by Flaherty $G$ et al. the majority of the individuals were not certain regarding their specific destinations within the countries they planned to visit [12]. In this setting, it is a challenge for the travel medicine specialist to perform an adequate risk assessment and to give the most appropriate travel health advice. Our second case had not been vaccinated before her travel even though she had planned to visit Ilha Grande. She did not see a travel medicine specialist before her trip and had found information on the Internet (website not specified) stating that the vaccination was not mandatory.

These two cases illustrate the importance of a pretravel consultation with a travel medicine specialist and the importance to adequately assess the risk of exposure to YF before a trip to a tropical country.

In conclusion, YF vaccination should be considered a priority for international travellers to endemic countries of Africa and South America. In addition, a second dose of YF vaccine for formerly vaccinated travellers could be recommended according to National recommendations and specific circumstances.

\section{Conflict of interest}

None declared.

Authors' contributions

Emma Oliosi wrote the manuscript and contributed to data collection, with support from Alexandre Bleibtreu and Eric Caumes.

Chantal Serero Corcos, Paulo Feijo Barroso, Gilda Grard and Ana Maria Bispo de Filippis contributed to data collection and analysis.

Eric Caumes directed the project and contributed to the writing of the manuscript.

All authors contributed to the manuscript and approved for the final version to be published.

\section{References}

1. Hamer DH, Angelo K, Caumes E, van Genderen PJJ, Florescu SA, Popescu CP, et al. Fatal yellow fever in travelers to Brazil, 2018. MMWR Morb Mortal Wkly Rep. 2018;67(11):340-1. https://doi. org/10.15585/mmwr.mm6711e1 PMID: 29565840

2. Gossner CM, Haussig JM, de Bellegarde de Saint Lary C, Kaasik Aaslav K, Schlagenhauf P, Sudre B. Increased risk of yellow fever infections among unvaccinated European travellers due to ongoing outbreak in Brazil, July 2017 to March 2018. Euro Surveill. 2018;23(11):18-00106. https://doi.org/10.2807/15607917.ES.2018.23.11.18-00106 PMID: 29560853

3. ProMED-mail. PAHO/WHO Epidemiological update: yellow fever. Archive Number 20180329:5716763. 29 March 2018. Available from: http://www.promedmail.org

4. European Centre for Disease Prevention and Control (ECDC). Yellow fever amongst travellers returning from South America, March 2017. Stockholm: ECDC; 2017. Available from: https:// ecdc.europa.eu/en/publications-data/yellow-fever-amongtravellers-returning-south-america-march-2017

5. Wouthuyzen-Bakker M, Knoester M, van den Berg AP. GeurtsvanKessel CH, Koopmans MP, Van Leer-Buter C, et al. Yellow fever in a traveller returning from Suriname to the Netherlands, March 2017. Euro Surveill. 2017;22(11):30488. PMID: 28333617

6. Newman AP, Becraft R, Dean AB, Hull R, Backenson B, Hale $G$, et al. Notes from the field: fatal yellow fever in a traveler returning from Peru - New York, 2016. MMWR Morb Mortal Wkly Rep. 2017;66(34):914-5. https://doi.org/10.15585/mmwr. mm6634a5 PMID: 28859053

7. Ministeria da Saude [Ministry of Health]. Febre amarela: Ministério da Saúde atualiza casos no país [Yellow fever: Ministry of Health updates cases in the country]. Brazil. $28 \mathrm{Mar}$ 2018. Available from: http://portalms.saude.gov.br/noticias/ agencia-saude/42916-febre-amarela-ministerio-da-saudeatualiza-casos-no-pais-5.

8. Centers for Disease Control and Prevention (CDC). Yellow fever. Atlanta: CDC; 2018. Available from: wwwnc.cdc.gov/ travel/yellowbook/2018/infectious-diseases-related-to-travel/ yellow-fever

9. European Centre for Disease Prevention and Control (ECDC). Assessing the yellow fever outbreak in Angola - European Medical Corps mission undertaken in the framework of the European Union Civil Protection Mechanism, 10-20 May 2016. Stockholm: ECDC; May 2016. Available from: https:// ecdc.europa.eu/sites/portal/files/media/en/publications/ Publications/yellow-fever-angola-joint-ecdc-missionreport-2016.pdf

10. Centers for Disease Control and Prevention (CDC). Yellow fever vaccine. Atlanta : CDC; Mar 2018. Available from: https://www. cdc.gov/yellowfever/vaccine/index.html

11. de la Haut C. Santé Publique [Public Council of Health]. Recommandations sanitaires pour les voyageurs, 2017. 
[Health recommendations for travellers, 2017]. France. 06 Jun 2017. Available from: http://invs.santepubliquefrance. fr/Publications-et-outils/BEH-Bulletin-epidemiologiquehebdomadaire/Archives/2017/BEH-hors-serie-

Recommandations-sanitaires-pour-les-voyageurs-2017.

12. Flaherty G, Md Nor MN. Travel itinerary uncertainty and the pre-travel consultation--a pilot study. J Travel Med. 2016;23(1):tav010. https://doi.org/10.1093/jtm/tav010 PMID: 26782127

\section{License and copyright}

This is an open-access article distributed under the terms of the Creative Commons Attribution (CC BY 4.0) Licence. You may share and adapt the material, but must give appropriate credit to the source, provide a link to the licence, and indicate if changes were made.

This article is copyright of the authors, 2018. 